\title{
Environmental competitiveness during the economic crisis
}

\begin{abstract}
The issue of enhancing competitive advantages at national and company level has gained considerably in importance due to the current financial and economic crisis. The environmental aspects of competitiveness have started to play an even more important role, despite the short-term negative consequences of the economic downturn and the arguments of some business leaders, politicians and researchers that environmentalism is too expensive. In contrast, the view of the author is that economic development and environmental improvements go hand-in-hand while, to maintain environmental competitiveness, as with economic competitiveness, standards and indicators must be continually improved. The article includes a brief look at what is being done to provide support to meet environmental targets in a selection of developed and developing countries, while the author concludes with a comment as to what might be done on this score in Russia to assist with structural change.
\end{abstract}

Keywords: environment, competitiveness, competitive advantage, climate change, renewable energy, energy efficiency, green economy, financial crisis, structural change

\section{Introduction}

The issue of environmental competitiveness has gained in importance due to the current unprecedented financial and economic crisis. The notion of 'environmental competitiveness' has been formulated relatively recently but it is no longer a new or unique phenomenon. By 'environmental competitiveness', we mean the ability to produce and sell goods efficiently, i.e. with a minimal depletion of natural resources. Maintaining environmental competitiveness, as with international competitiveness, requires the continual improvement of the main indicators (here, environmental ones), regardless of the contemporary conditions of severe competition.

\section{Negative impact of financial crisis}

Lately, many business leaders, politicians and even some researchers have started to claim that environmental policy (including measures to reduce global warming) is too expensive; an 'unnecessary luxury' during the economic downturn. According to these people, a large majority of environmental policy measures, including the setting up of carbon emissions trading, require not only considerable financing but also the establishment of a relevant organisational framework, infrastructure and other additional measures. In their opinion, companies can not afford the additional environmental costs 
while they are struggling to control costs so as to survive and maintain market share and, for this reason, states should postpone 'until better times' the introduction of new environmental taxes and the implementation of other instruments of environmental policy.

An example is that some EU countries, i.e. Poland, Hungary, Slovakia, Bulgaria and Romania, have recently expressed interest in postponing the introduction of active polices in the area of climate change - currently the most complex and difficult environmental problem and one which also has a long-term impact. Politicians in some other countries have expressed their concerns over the tightening of EU plans to reduce carbon emissions (policies voted for by the European legislature) due to the potential cost increase for national companies (at the same time, leaders of other EU countries, most notably France, have insisted on the implementation of the new obligations passed).

It is true that environmental measures, certainly the most radical ones, can be costly, requiring a complicated organisational framework for the introduction of new technologies and, sometimes, even structural adjustments across particular industries. An example is the issue of global warming: this problem may most probably be solved but only with the radical restructuring of the entire energy sector.

However, the current situation is rather unique in favouring improvements in both the environment and in competitiveness. The economic crisis and the limited availability of many types of natural resources, above all energy, has made evident the multitude of structural and resource-related problems, challenging states and companies alike to use these much more efficiently. This is a target entirely in line with environmental protection policies and one that contributes to an increase in national and company-based competitive advantage.

Important factors contributing to the implementation of an environment-related policy (even during a time of economic crisis) can be mentioned as including the honouring of international and national commitments; the general awareness of the population of the degradation of the environment, which is continuing to increase; the need to improve health and the quality of life of the people; and other factors.

\section{Opportunities to develop an environmental competitive advantage}

Opportunities to maintain and develop environmental competitiveness are related to cost reductions in the usage of energy, water and other resources and waste management, since the prices of the main resources and of waste disposal costs are continuously rising. Higher competitiveness due to the reduced usage of resources is clearly visible in countries such as Germany, the United Kingdom, France and Japan.

Competitive advantage can be achieved by the introduction of modern technologies, conducive to gaining new markets, including the dynamically-developing environmental market. The size of this market is currently estimated to be worth in the range of \$900-2 000bn, which is comparable with the aerospace and pharmaceuticals markets. The figure does not include some completely new markets related to the development of technologies to control global warming. Over the next years, the environmental market is expected to grow even more rapidly. 
Quite a few countries and many companies are already trying to use the current economic situation to carry out structural reforms, allowing at the same time the reduction of dependence on a whole range of imported resources, the improvement of the environmental situation and an the increase in competitive advantage, as well as a means of overcoming the crisis.

Issues in the improvement of national environmental policies and the simultaneous increase in competitive advantage in the conditions of economic crisis have been addressed by international organisations (UN General Assembly, OECD and others); regional trading blocs (EU, NAFTA); and by individual countries. One example is that the issue of maintaining competitiveness when carrying out environmental protection measures was specifically included on the agenda of the meeting of the ministers of the OECD's Environmental Policy Committee (EPOC) in April 2008, while the same issue was being addressed during several high-level meetings within the EU. Some politicians express the opinion that only a proper consideration of environmental requirements will help to turn around economies and overcome the crisis. Besides, environmental measures can help to create new jobs, as US President Barack Obama has pointed out in several of his speeches.

The majority of states have expressed a readiness to sign the new carbon emission agreement in December 2009 in Copenhagen, as a replacement for the Kyoto Protocol which expires in 2012. During the UN Climate Change Conference held in December 2008 in Poznan, Poland (i.e. at the high point of the financial crisis), representatives of the 192 participating countries confirmed their intentions to reduce $25-40 \%$ of the 1990 level of greenhouse gas emissions by 2020 which, according to the majority of researchers, constitute the main reason for continuing global warming.

\section{Developed country examples}

An active environmental policy has become the basis of, and even a priority for, the national and regional strategies of developed countries. Furthermore, the implementation of such strategically structured and predictable policies is quite often required by business.

An example here is the Aldersgate Group, a coalition between major UK companies (including Tesco, Johnson Matthey, ACCA, BT, United Utilities and others) and environmental organisations, which requested in December 2008 that the government use the unique opportunity provided by economic reform to improve environmental indices, increase competitiveness and thus overcome the economic crisis. Environmental legislation is considered by companies as the main vehicle for improving their competitive positions.

The EU is realising the importance of the effort to reduce and avoid negative impacts on the environment and to promote sustainable patterns of production and consumption. In July 2009, the European Commission adopted the 2009 Review of the EU Sustainable Development Strategy. This underlines that, in recent years, the EU has mainstreamed sustainable development into a broad range of its policies. ${ }^{1}$ The European Economic Recovery Plan 2010-2013, adopted in 2009 as a means of responding to the current

1 http://ec.europa.eu/environment/eussd/. 
economic crisis, includes quite a number of green initiatives with a focus on energy saving and climate change-related measures.

Recently, despite the crisis, at the EU Summit in Brussels in December 2008 members took the decision to increase the energy efficiency of their economies by $20 \%$ and the usage of renewable energy sources for energy generation (such as wind and solar power) by $20 \%$ as a means of reducing carbon dioxide emissions by 2020 (the '20-20-20 target'). Special attention is being paid to transport, which generates approximately one-third of all greenhouse gas emissions in the EU. Members of the Union think that achieving these goals will allow them to improve the environment, reduce costs and increase competitiveness.

Industry-specific programmes are being developed to achieve these targets. For example, concerning the introduction of technologies in the area of hydrogen energy and in fuel cells, the Joint Technology Initiative, a public-private partnership, is being supported. This organisation has received an EU grant amounting to $€ 470 \mathrm{~m}$. The EU Labelling Directive requires the compulsory indication of fuel consumption and carbon dioxide emissions for all new vehicles.

Environmental legislation is being constantly tightened. For example, in order to limit the pollution caused by road vehicles, the EU recently introduced Euro 5, a new set of common requirements for emissions from motor vehicles, and is already preparing regulations for Euro 6, which will come into force on September 2014. The new Renewable Energy Directive requires that $10 \%$ of motor fuels by 2010 are produced from renewable energy sources.

EU member states are also developing their own 'green policies'. Many of them are actively using the directive and economic instruments of government environmental policy, including taxes, subsidies and other measures within the context both of EU common policies and within the scope of the individual incentives provided by their own governments.

Germany has carried out tax reform targeting the lower usage of fossil fuels, which are a source of carbon dioxide emissions, and increasing the usage of alternative energy sources. In many respects, due to the implementation of such tax incentives, Germany now ranks third in the world for wind energy generation and has become the EU leader in solar energy generation. The main target of the reform is transfers towards the scale generation of alternative energy sources and the gradual reduction of their prices which, ultimately, will allow the reduction of subsidies for environmentally-clean energy sources and the increased competitiveness of this new industry.

In the UK, the introduction of the national Envirowise programme, targeting lower resource usage and thus the reduction of negative environmental impacts, has from as early as 1994 allowed local companies to cut costs and save as a result, by 2003, more than $£ 800 \mathrm{~m}$. The introduction of yet another programme - the Waste and Resources Action Programme (WRAP) in 2000 - has allowed UK companies to increase the sale of recycled products.

Currently, despite the economic crisis, the UK government has allocated multimillion pound subsidies to buyers of electric cars, ranging from $£ 2000-£ 5000$ per buyer. Such a policy seeks to stimulate the activities of producers of environmentallyclean cars (presently less than $0.1 \%$ of all cars in the country are run on electricity). 
The goal of these measures is both the reduction of carbon dioxide emissions within the framework of the Kyoto Protocol as well as increased competitiveness.

The UK is continuing to carry on with the implementation of energy efficiency and energy saving programmes. Special attention is being paid to the reduction of household energy consumption. So far, over ten million houses in the country do not have basic heat insulation, which increases household expenditure. Just putting in such insulation will create 20000 new jobs, which would be an important development factor in the crisis conditions.

France is currently a country with one of the lowest levels of carbon dioxide emissions, being $20 \%$ lower per capita compared with the EU average and 30-40\% lower compared to other large countries of the Union. This is the result of large-scale investments in the reduction of car exhausts: French car parks are one of the most ecologically clean in Europe.

In the last years the Grenelle Environment programme has been developed in the country. This has provided for the modernisation of all buildings and the increase of their energy efficiency, as well as the financing of research in the area of new types of transport. In 2008, a target was set to stimulate demand so as to overcome the crisis and to change consumer preferences. To fulfil this programme, a bonus scheme is used to pay the buyers of more ecologically clean vehicles (during the first eight months of 2008 , over 500000 such bonuses had been allocated), which has substantially increased the demand for such products and has stimulated their manufacture. The modernisation of buildings within the framework of this programme to reach the goal of a $30-40 \%$ reduction in energy produced per unit by 2020 will allow for the development of the construction industry.

Italy is currently carrying out reforms in order gradually to shift to more environmentally clean energy sources. For example, the usage of 'green certificates' trading has allowed the stimulation of the production of alternative energy sources, mostly by support for the generation of solar energy. Part of the reform concerns energy usage in transportation and in buildings by the setting of special requirements for industrial, office and domestic equipment.

The Denmark example demonstrates that it is possible to stimulate economic growth and to reduce environmental impact at the same time. In the last 25 years, the country's economy has grown by $75 \%$ while the emission of greenhouse gases has reduced by $16 \%$. In the future, Denmark is planning not to use fossil fuels at all. In the crisis conditions, a target has been set to increase the share of renewable energy in the total energy supply from the current level of $15 \%$ to $20 \%$ by 2011 and to at least $30 \%$ by 2025 . These targets will be achieved by the construction of new windmills and the increased usage of biomass in energy generation, as well as energy efficiency improvements. By 2011, overall energy consumption should be reduced by $2 \%$ compared to the 2008 level and by $4 \%$ by 2020 . Newly-built houses should by 2020 use only one-quarter of the energy currently consumed. All energy generation companies in the country will have to comply with the reduced energy, heat and gas usage targets which have been set. 
Sweden has set the goal of achieving a completely oil-free economy by 2020 without building more nuclear power plants. The Swedish government plans to replace all fossil fuels with renewable alternatives.

The US Congress and Senate adopted in 2009 one of the most ambitious plans in their history as regards the economy and the environment - The American Recovery and Reinvestment Act includes more than $\$ 80$ billion in clean energy investments that will help to recover and build clean energy for the economy.

\section{Developing country examples}

Developing countries have also started to realise that the negative effects caused by the financial crisis can be compensated for by a restructuring of the economy. Some of them have tried to revive development by 'greening' their economy.

Recently, China has been targeting the issue of lowering the emissions of carbon dioxide from its rapidly growing industrial and transportation sectors. Furthermore, China has allocated 4 trillion yuan out of its $\$ 584$ bn economic stimulus plan aimed at reviving the economy towards a transformation of high energy-consuming industries into more environmentally-friendly ones. The country has set a goal of increasing renewable energy consumption to 10 per cent by 2010 and to 15 per cent by 2020 by building up hydro, nuclear, solar and wind power capacities.

India adopted its National Action Plan on Climate Change in 2008. The plan provides for a switch to the 'green economy' and contains measures promoting India's development objectives while also yielding co-benefits for addressing climate change effectively. The plan focuses on harnessing renewable energy. The new renewable energy policy targets an increase in electricity generation from renewable energy sources to $10 \%$ by 2010 and to $20 \%$ by 2020 of total electricity generation in the country.

\section{Industry examples}

Quite a number of industries, despite the crisis, continue to invest in new technologies. Car industry companies, which are the biggest private investors in EU R\&D, have allocated major funds for the development and introduction of energy-saving technologies allowing for reduced fuel consumption and lower carbon dioxide emissions.

Major companies are taking measures to use the current conditions as an opportunity to improve their market situation. For example, Alcoa, the world's third largest producer of aluminium, in order to reduce costs and maintain its competitive position in the circumstances of crisis and the fall in aluminium prices, has started to replace nonobsolete equipment at its plant in Rockdale (Texas). Such measures do not always generate an immediate pay-off and are characteristic of companies with strategic interests counting on long-term profit generation.

Even more importantly, the allocation of financial funds for environmental policies in these conditions of crisis is an absolute imperative. Current environmental spending is clearly insufficient to improve the environment radically. This is especially relevant for the most acute problems, such as global warming. Recent research and reports (Stern report; OECD environmental overview) demonstrate that, in the future, the global economy will have to incur huge financial costs in fighting the consequences of the current 
environmental situation. Many politicians and company representatives underline that the global economy will, at some stage, overcome the financial crisis, but the more serious problem of how to overcome the ecological crisis will persist thereafter.

Many companies are using environmental leverage to gain market share. Airbus, for example, has signed a contract with Persian Gulf countries to supply passenger jets with high environmental qualities amounting to $\$ 15.2 \mathrm{bn}$.

\section{Russia}

The issue of improving environmental competitiveness is even more acute in the crisis environment for Russia, whose economic structure makes the country even more vulnerable to changes in the global market situation. Russia does not have the financial funds that are available to developed countries. However, the crisis provides the unique opportunity to carry out structural changes in the economy by substantially increasing the efficiency of the usage of energy and other resources. To achieve those goals, it is necessary to extend the usage of incentives, an extremely important instrument, as a means of stimulating investment in environmentally-clean industries and to introduce new technologies (for example, the usage of alternative energy sources, where we have a huge potential). This will help to overcome the crisis in the shortest possible time and to achieve long-term economic growth based on environmentally-clean production and consumption.

It will not be correct to say that all environmental policy measures are costly and expensive. In the contemporary conditions, targeting environmental competitiveness can help Russia gain a more adequate position in the global economy.

\section{Acknowledgements}

I wish to thank Bruno S. Sergi, member of the Editorial Board of the SEER, and also two anonymous referees for their valuable comments on an earlier draft of this paper.

\section{References}

Aldy, Joseph E and Robert N. Stavins (Eds.) (2009) Post-Kyoto International Climate

Policy: Implementing Architectures for Agreement New York: Cambridge University Press.

Bendavid-Val, Avrom and Nicholas Cheremisinoff (2003) Achieving Environmental Excellence: Integrating P2 and EMS to Increase Profits Rockville, MD: Government Institutes.

Bendavid-Val, A and C. Perine (2003) Environmental competitiveness: completing the competitiveness paradigm Chemonics International Inc: Washington, July 8.

Block, M (2000) Identifying Environmental Aspects and Impacts New York: McGrawHill.

'Cleaner and greener' Public Service Review: Science and Technology Issue 28 April 2009. 
Kanter, J (2009a) 'New subsidies for electric cars in Britain' New York Times Energy \& Environment, 16 April http://greeninc.blogs.nytimes.com/2009/04/16/new-subsidies-for-electric-cars-in-britain/

Kanter, J (2009b) 'Poland Leads Charge to Delay European Climate Reforms' New York Times Energy \& Environment, 20 April.

OECD (2008) Climate change mitigation: what do we do OECD Publishing.

OECD (2009) Strategic Response to the Financial and Economic Crisis: Contributions to the Global Effort OECD.

Official Journal of the European Union (2009) Directive 2009/29/EC of the European Parliament and of the Council of 23 April 2009 amending Directive 2003/87/EC so as to improve and extend the greenhouse gas emission allowance trading scheme of the Community OJ L 1406 June 2009, p. 63.

Porter, M The Competitive Advantage of Nations New York: The Free Press, 1990 and 1998.

Пусенкова Н.Н (2007) Солнцева Е.А. Российские компании в 21 веке: повышая конкурентоспособность и корпоративную ответственность. Исследование Программы по торговле и инвестициям WWF WWF России.

Stern, N (2007) The Economics of Climate Change: The Stern Review Cabinet Office, HM Treasury.

\section{Websites:}

www.best-europe.org

www.biogasmax.eu

www.biac.org

www.civitas-initiative.eu

www.denmark.dk

www.ec.europa

www.expert.ru

www.gazprom.ru

www.global-hydrogen-bus-platform.com

www.insurancejournal.com/news/international/2008/12/29/96609

www.iso.ch

www.legrenelle-environnement.fr. 
www.lukoil.ru

www.ndems.cas.unc.edu

www.neurope.eu

www.nlmk.ru

www.oecd.org

www.rosneft.ru

www.severstal.ru

www.tnk-bp.ru

www.tradeforum.org 